\title{
Analisis Penggunaan Hadis dalam Khutbah Jumat di Kota Kendari
}

\author{
Akbar Akbar \\ Fakultas Ushuluddin Adab dan Dakwah IAIN Kendari \\ akbar@iainkendari.ac.id
}

\begin{abstract}
This study aims to examine the use of hadith in the Friday sermon in terms of its intensity, method of delivery, and quality of reference and the quality of hadith delivered by the preachers in the mosques of Kendari City. Similar studies have been carried out in several regions in Indonesia, but the city of Kendari has not been touched by this urgent research in order to identify the quality of dakwah and diversity which is one of the main parts of concern is the Prophet's hadith as the main reference in Islam along with the Qur'an with the unique characteristics are different from the Qur'an. The research was carried out by recording the sermon process that took place in the mosques and then processed and analyzed with the validity of the hadith approach. The results showed that the use of hadith in the sermon in Kendari City was high, even though it was not evenly distributed. There were a number of errors in delivery both in terms of reading, wrong hadith texts, and even mistakenly claiming the hadith as a verse, including validating false hadiths. On the other hand, the hadiths conveyed by the majority preachers are hadiths which can be used as proofs in the form of sahih and hasan level and sourced from standard books, the quantity is very high compared to the hadiths of da'if and maudhu' which are very low.
\end{abstract}

Keywords: Friday Sermon, use of Hadith, quality of Hadith

\begin{abstract}
Abstrak
Penelitian ini bertujuan untuk mengkaji penggunaan hadis dalam khutbah Jumat baik dari segi intensitasnya, metode penyampaian, maupun kualitas rujukan dan kualitas hadis yang disampaikan oleh para khatib di masjid-masjid Kota Kendari. Penelitian sejenis sudah dilakukan di beberapa wilayah di Indonesia, namun kota Kendari belum tersentuh penelitian yang urgen ini dalam rangka mengidentifikasi kualitas dakwah dan keberagamaan yang salah satu bagian utamanya adalah perhatian yang serius terhadap hadis Nabi saw. sebagai rujukan utama dalam beragama Islam bersama dengan al-Qur'an dengan karakteristik yang banyak perbedaan dengan al-Qur'an. Penelitian dilakukan dengan melakukan recording atas proses khutbah yang berlangsung di masjid-masjid kemudian diolah dan dianalisis dengan pendekatan kaidah kesahihan hadis. Hasil penelitian
\end{abstract}


menunjukkan bahwa penggunaan hadis dalam khutbah di Kota Kendari terbilang tinggi, meski tidak merata. Ditemukan sejumlah kekeliruan dalam penyampaian baik dari segi bacaan, teks hadis yang keliru, bahkan salah mengklaim hadis sebagai ayat, termasuk men-sahih-kan hadis palsu. Di sisi lain, hadis-hadis yang disampaikan oleh khatib mayoritas adalah hadis-hadis yang dapat dijadikan hujjah berupa hadis sahih dan hasan dan bersumber dari kitab-kitab standar, kuantitasnya sangat tinggi dibanding hadis da'if dan maudhu' yang sangat rendah.

Kata kunci: Khutbah Jumat, penggunaan Hadis, kualitas Hadis

\section{A. Pendahuluan}

Sebuah fenomena ditemukan di beberapa masjid di Kota Kendari yaitu khatib Jumat sama sekali tidak menyampaikan dalil di dalam khutbahnya, seperti yang terjadi di masjid Lorong Simbo Kota Kendari pada sebuah Jumat di bulan Februari 2017. Dalam kesempatan lain ditemukan pula seorang khatib yang menyampaikan hadis yang sesungguhnya bukan sabda Nabi Muhammad saw. (Masjid Brimob, Ramadhan 2017). Fenomena seperti ini memprihatinkan mengingat bahwa hadis adalah sumber utama ajaran Islam bersama al-Qur'an, bahkan hadis Nabi Muhammad saw. Berfungsi sebagai penjelaspenafsir terhadap al-Qur'an (bayan). Dengan kedudukan dan fungsi hadis yang demikian penting, maka hadis seharusnya mendapatkan porsi yang sama pentingnya dengan alQur'an dalam penyampaian ceramah-ceramah keagamaan Islam, khususnya khutbah Jum'at yang merupakan bagian dari kewajiban mingguan setiap lelaki balig.

Sebagaimana diketahui, khutbah adalah media dakwah yang paling dimanfaatkan oleh Nabi di awal Islam (Thaib, 4AD). Namun khutbah Jum'at berbeda halnya dengan ceramah keagamaan lainnya karena memiliki rukun tertentu yang wajib diikuti oleh setiap khatib. Menyampaikan pesan-pesan takwa yang diperintahkan dalam khutbah harus diiringi dengan membacakan minimal satu buah ayat al-Qur'an dan atau hadis Nabi saw. Memang menyampaikan sebuah hadis bukanlah rukun khutbah, namun sangat aneh jika seorang menyampaikan ayat al-Qur'an namun tidak sedikitpun menyinggung hadis Nabi saw. padahal hadis Nabi saw. adalah tafsir yang paling sahih dari al-Qur'an. 
Berbeda halnya dengan al-Qur'an, tidak semua hadis Nabi mutawatir sehingga memiliki tingkat otentisitas yang berbeda-beda. Jika al-Qur'an semuanya qat'iy (pasti), justru hadis Nabi disebut zhanniy (tidak pasti), karena hadis ada yang sahih, hasan, dha'if, bahkan ada yang maudhu' atau palsu. Hal inilah yang menjadikan hadis memerlukan perhatian khusus, karena dibutuhkan selektifitas dalam menjadikannnya sebagai argumentasi atau dalil beragama termasuk menjadikannya sebagai materi khutbah (Rusli \& HPW, 2017).

Selektifitas dalam menjadikan hadis sebagai dalil menjadi tuntutan tersendiri karena merujuk kepada sebuah peringatan tegas dari Nabi Muhammad saw. sendiri dalam sebuah hadis mutawatir bahwa "Barang siapa yang dengan sengaja berbohong atas diriku, maka dia harus menyiapkan sendiri tempat duduknya di neraka”. Peringatan Nabi saw. tersebut menyasar orang-orang yang menyandarkan "pernyataan" kepada Nabi saw. dengan sengaja padahal pernyataan itu bukan pernyataan Nabi saw. Hadis mutawatir ini memperingatkan untuk berhati-hati untuk menyandarkan hadis kepada Nabi saw. dengan cara memastikan bahwa hadis yang dikutip atau disampaikan, khususunya dalam ceramah atau khutbah yang menyasar masyarakat umum adalah hadis yang maqbul (diterima) berdasarkan kriteria ilmu hadis yang ditetapkan para ulama hadis.

Penelitian ini sangat urgen mengingat bahwa penelitian terkait belum ditemukan adanya di Kota Kendari. Khutbah sebagai salah satu basis pembimbingan dan pengembangan umat Islam agar penggunaan hadis sebagai dasar semakin dakwah semakin disadari dan bukan sekadar retorika, serta tidak memuat dalil-dalil yang tidak otentik yang dapat menyesatkan dan menjerumuskan umat.

Berdasarkan latar di atas, masalah utama penelitian ini adalah bagaimana penggunaan hadis dalam khutbah di Kota Kendari. Masalah tersebut dibreakdown menjadi: Bagaimana tingkat penggunaan dan ragam penyampaian hadis serta otentisitas hadis yang disampaikan dalam khutbah Jumat di Kota Kendari?

\section{B. Metode Penelitian}


Penelitian ini adalah gabungan library-field research, yang menggunakan metode kualitatif dengan analisis deskriptif-analitik. Penelitian dilakukan dengan mengumpulkan materi hadis khutbah selama rentang waktu Juli-Oktober 2018 dari 21 masjid yang berbeda dan diperoleh data sejumlah 47 rekaman khutbah. Selanjutnya dilakukan uji kualitas hadis dengan terlebih dahulu melakukan penelusuran dengan metode Takhrij Hadis dengan metode penelusuran kualitas hadis.

Instrumen penelitian ini adalah instrumen standar untuk menentukan otentitas data hadis yang orisinil dari Nabi Muhammad saw. menggunakan hasil penilaian para ulama seperti Imam al-Bukhari, Imam Muslim, Imam Ibn Hibban, Al-Albani, dan kritikus lainnya. Hasil penilaian ulama kemudian digunakan sebagai bahan untuk menyimpulkan hasil kualitas hadis.

\section{Metode penggunaan hadis dan kualitas hadis khutbah Jumat}

\section{C.1. Penggunaan hadis dalam Khutbah}

Pada bagian ini penulis memberikan gambaran terhadap 3 hal yaitu tingkat penggunaan hadis dalam khutbah, metode penyampaian hadis, dan kualitas penyampaian hadis.

a. Tingkat Penggunaan hadis

Penggunaan hadis dalam khutbah yang diperoleh melalui data rekaman berjumlah 76 hadis dengan beragam bentuk penyampaian, mulai dari yang disebutkan sanad, matan, dan mukharrijnya, sampai yang disebutkan dalam bentuk terjemahan saja. Jumlah total 76 hadis tersebut terkesan banyak jika dipresentasikan dari 47 data khutbah, karena jika dirata-ratakan setidaknya satu orang khatib menyampaikan lebih dari satu hadis dalam khutbahnya. Namun kesan tersebut tidak sepenuhnya benar, karena setelah diamati, ditemukan fakta bahwa dari 47 khatib yang menyampaikan khutbah, terdapat 14 khatib yang tidak menyampaikan hadis sama sekali. Hal ini bermakna bahwa hanya 33 dari 47 khatib atau $70 \%$ di antaranya yang menyampaikan hadis dalam khutbahnya. Jika dipresentasikan lagi dari 33 khatib yang menyampaikan khutbah, maka rata-rata setiap khatib menyampaikan masing-masing 2 hadis, meski kenyataannya 12 khatib hanya menyampaikan 1 hadis saja. 
Jika dilihat secara total jumlah hadis dan dirata-ratakan maka tingkat perhatian khatib untuk menggunakan hadis dalam khutbah mereka dianggap cukup. Hanya saja, melihat adanya $30 \%$ khatib yang tidak menggunakan hadis dalam khutbahnya menunjukkan bahwa tingkat perhatian tersebut tidak merata.

Adapun jika ditinjau dari jumlah 76 hadis yang disebutkan dalam khutbah, ternyata terdapat 10 hadis yang muncul lebih dari sekali karena disebutkan oleh beberapa khatib yang berbeda, sehingga total akhir hanya terdapat 66 hadis.

\section{b. MetodelBentuk Penyampaian}

Metode atau bentuk penyampaian yang dimaksud adalah ragam cara khatib memaparkan hadis. Hal ini tidak bermaksud mengklaim keliru atau tidaknya cara penyampaian hadis, tetapi lebih bertujuan untuk menganalisis adanya indikasi khatib untuk mengedukasi jama'ah terkait hadis sebagai sumber ajaran Islam yang faktanya berbeda dengan al-Qur'an. Perbedaan yang dimaksud adalah:

1) Bahwa hadis tidak terhimpun dalam satu mushaf atau kitab tertentu seperti halnya al-Qur'an, sehingga mengetahui rujukan/sumber hadis adalah sebuah kebutuhan.

2) Bahwa hadis sampai kepada kita melalui para Imam Hadis dengan metode periwayatan dari Nabi saw. sampai kepada mereka para penulis kitab hadis (mukharrij), sehingga mengetahui para periwayatnya paling tidak sahabat yang meriwayatkannya akan menjadi lebih afdhal (minimal dalam konteks edukasi)

3) Bahwa hadis tidak semuanya sahih dan pasti kebenarannya sebagaimana ayat al-Qur'an, sehingga kualitas hadis penting untuk disampaikan dan diketahui oleh jama'ah yang mendengarkan khutbah sebagai bagian dari edukasi sekaligus meyakinkan jamaah dalam mempercayai dan mengamalkan hadis yang disampaikan.

Dengan gambaran perbedaan di atas, maka idealnya (meski tidak wajib) hadis disampaikan kepada jama'ah dengan lengkap berupa sanad, matan, mukharrij (periwayat terakhir), dan bahkan status atau kualitas hadis. Hal tersebut tentu tidak mempengaruhi kualitas khutbah secara langsung (sah atau tidak), tetapi 
dalam rangka memberi pelajaran kepada masyarakat bahwa hadis yang disampaikan dapat dipertanggungjawabkan, dapat ditelaah, dan dapat diyakini kebenarannya dari Rasulullah saw. Dan bukan mengada-ada.

Data yang diperoleh dalam penelitian ini menunjukkan metode penyampaian hadis oleh khatib yang beragam. Setidaknya ada 6 klasifikasi metode penyampaian hadis yang peneliti temukan dalam penelitian ini:

1) Hadis disampaikan oleh khatib dengan menyebutkan matan hadis beserta nama sahabat (periwayat pertama) disertai dengan mukharrij (periwayat terakhir sebagai pemilik kitab rujukan) tanpa menjelaskan kualitasnya, yaitu sebanyak 4 hadis.

2) Hadis disampaikan oleh Khatib dengan menyebutkan matan hadis beserta periwayat sahabat saja tanpa mukharrij tanpa menjelaskan kualitasnya, yaitu sebanyak 2 hadis.

3) Hadis disampaikan oleh khatib dengan menyebutkan matan hadis disertai nama mukharrij tanpa nama sahabat dan tidak menyebutkan kualitasnya, yaitu sebanyak 5 hadis.

4) Hadis disampaikan oleh khatib dengan menyebutkan matan hadis disertai kualitas hadis tanpa menyebutkan periwayat dan mukharrij nya, yaitu sebanyak 3 hadis.

5) Hadis disampaikan oleh khatib dengan menyebutkan matan dalam Bahasa Arab (potongan hadis) tanpa keterangan periwayat, mukharrij, dan kualitas hadis, yaitu sebanyak 55 hadis.

6) Hadis disampaikan oleh khatib dengan tidak menyebutkan matan hadis dalam Bahasa Arab melainkan terjemah atau makna umumnya saja termasuk tidak menyebutkan periwayat dan mukharrij, yaitu sebanyak 7 hadis.

Berdasarkan pemaparan di atas, di dalam penyampaian khutbah Jumat di Kota Kendari tidak ditemukan adanya satu hadis pun yang disampaikan dalam bentuk idealnya yaitu menyampaikan sanad, mukharrij, dan beserta kualitasnya. Lebih dari itu, 55 dari 76 atau $72 \%$ hadis matannya saja sekadar disampaikan makna dan kandungan hadis, bahkan 7 hadis diantaranya disampaikan terjemahnya tanpa disebutkan teks Arab-nya apalagi keterangan lainnya. Meski 
tidak berpengaruh kepada keabsahan khutbah, hal tersebut setidaknya merupakan wujud dari kurangnya perhatian para khatib untuk memberi edukasi kepada jamaah terkait hadis Nabi saw. yang memiliki keunikan tersendiri dibanding alQur'an.

\section{c. Kualitas Penyampaian hadis}

Kualitas pembahasan yang dimaksud pada bagian ini adalah kualitas pembacaan hadis oleh khatib. Pembahasan ini pada dasarnya berhubungan dengan sub sebelumnya, namun memiliki penekanan sendiri dalam hal kualitas bacaan dan atau pengetahuan khatib itu sendiri terhadap teks arab dan hadis Nabi saw.

Sub pembahasan ini dimaksudkan untuk memaparkan fenomena yang ditemukan dalam penelitian bahwa terdapat setidaknya 3 khatib yang tidak bisa membaca ayat dan atau hadis dengan benar meskipun nyatanya mereka sedang membaca teks (bukan menghafalkannya). Lebih dari itu, peneliti juga menemukan adanya khatib yang tidak keliru dalam menyatakan sebuah hadis yang diklaimnya sebagai ayat al-Qur'an.

Sekiranya kejadian tersebut adalah kasuistik dan tidak merepresentasikan khatib-khatib lainnya - karena kesalahan pembacaan dilakukan oleh 2 khatib dan kesalahan klaim hadis sebagai ayat oleh 1 khatib - paling tidak kasus tersebut menjadi gambaran masih adanya sejumlah khatib yang belum fasih dan belum melakukan proses pembelajaran yang serius sebelum menyampaikan khutbah yang notabene merupakan sarana menyampaikan ajaran agama yang berbasis wahyu yaitu al-Qur'an dan Hadis Nabi saw.

Peneliti juga menemukan banyak hadis yang disampaikan seperti periwayatan makna, karena banyak kekeliruan redaksi matan hadis meskipun maksudnya dapat dipahami dan tidak keliru. Sehingga hadis-hadis tersebut sulit atau bahkan tidak ditemukan lafalnya dalam kitab-kitab hadis karena menggunakan kosakata yang berbeda meskipun makna hadisnya tetap sama.

\section{d. Kitab Rujukan Hadis Khutbah Jumat}

Sub pembahasan ini khusus untuk memetakan rujukan yang merupakan sumber hadis-hadis yang diperoleh dari data khutbah yang berhasil dikumpulkan dalam penelitian ini. Setelah diadakan takhrij/penelusuran hadis, dari 66 hadis 
yang ditemukan dalam khutbah ternyata 2 diantaranya tidak ditemukan dalam kitab-kitab hadis, yaitu hadis tentang masa depan dan hadis yang disebut mauquf dari Ali bin Abi Talib.

Secara umum, dari 64 hadis tersebut, 53 diantaranya ditemukan dalam kitab standar (mu'tabar) yaitu al-kutub al-tis'ah (kitab sembilan) yaitu Kitab Sahih al-Bukhari, Sahih Muslim, Sunan Abu Dawud, Sunan Ibn Majah, Sunan alDarimi, Sunan al-Tirmizi, Sunan al-Nasa'i, Musnad Ahmad, dan Muwattha' Malik, sementara 11 hadis lainnya ditemukan dalam kitab-kitab gair mu'tabar (tidak standar) seperti Kitab Musnad Abu Dawud al-Tayalisi, Sunan al-Sugra alBaihaqi, Musnad al-Harist, Syu'ab al-Iman, Mushannaf Ibn Abi Syaibah, Mu'jam al-Ausath al-Tabrani, Musnad al-Syihab, Mushannaf Abd al-Razzaq, Sunan alDaruquthni, dan Al-Sunnah Ibn Abi Ashim.

Berdasarkan gambaran di atas, dapat dinyatakan bahwa rujukan-rujukan hadis yang digunakan oleh khatib dalam khutbah Jumat di Kota Kendari mayoritas adalah kitab-kitab standar, dimana 53 hadis atau 79\% dari hadis secara keseluruhan dapat ditemukan di dalam kitab-kitab standar. Namun hal ini masih sebatas rujukan, adapun tentang kualitas hadis-hadis tersebut akan dibahas pada bagian sub pembahasan berikutnya.

\section{C.2. Analisis Kualitas dan Kehujjahan Hadis Khutbah Jumat}

Sebagaimana dijelaskan pada sub pembahasan sebelumnya, bahwa total hadis yang ditemukan dalam penelitian ini adalah 66 hadis (tanpa hadis yang berulang), 64 diantaranya dapat ditemukan dalam kitab hadis dan dua diantaranya tidak ditemukan setelah proses takhrij. Pada bagian ini, kualitas masing-masing dari 64 hadis tersebut akan dijelaskan berdasarkan khutbah masing-masing:

Hadis 1:

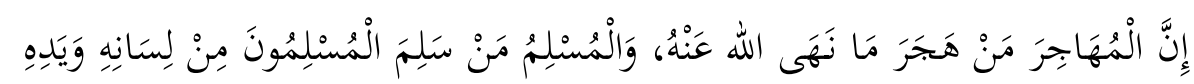

Hadis ini diriwayatkan oleh Imam Ahmad dalam al-Musnad melalui Abdullah bin Umar. Hadis ini juga diriwayatkan melalui jalur lain yaitu Al-Sya'bi sebagaimana dalam riwayat Al-Bukhari. Ahmad Muhammad Syakir dalam tahqiq kitab Musnad menjelaskan bahwa hadis ini hadis Sahih (Hanbal, 1995: Juz VI, 78). Senada dengan penjelasan Syuaib al-Arnauth dalam Sahih Ibn Hibban (Al-Busti, 1988: I, 425). Dengan demikian, hadis ini disimpulkan sahih. 
Hadis 2:

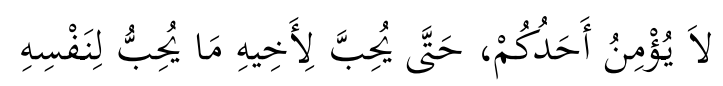

Hadis ini diriwayatkan dalam tujuh kitab standar, khususnya oleh al-Imam alBukhari (Al-Bukhari, 1422: I, 12) dan al-Imam Muslim (Al-Qusyairy, 2000: I, 67). Dengan demikian hadis ini dihukumi sahih.

Hadis 3:

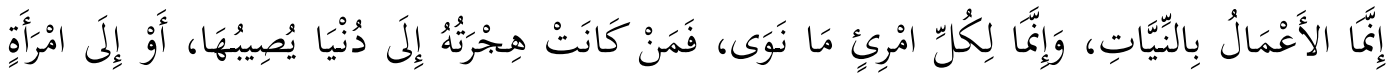

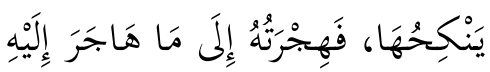

Hadis ini diriwayatkan setidaknya dalam empat kitab standar, khususnya oleh alImam al-Bukhari (Al-Bukhari, 1422: I, 6) dan al-Imam Muslim (Al-Qusyairy, 2000: III, 1515). Dengan demikian hadis ini dihukumi sahih.

Hadis 4:

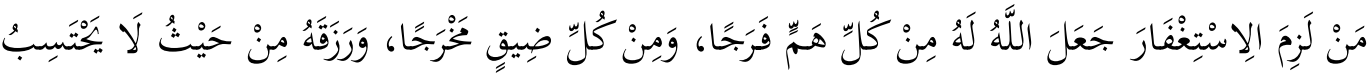
Hadis ini diriwayatkan oleh Imam Ibn Majah dan Imam Abu Dawud dari Abdillah bin Abbas. Hadis ini disepakati dinilai da'if oleh Syuaib al-Arnauth (Majah, 2009: IV, 721) dan Al-Albani (Al-Albani, 1420: II, 97) karena adanya periwayat alHakam bin Mus'ab yang dianggap majhul. Maka hadis ini disimpulkan berkualitas $d a$ 'if.

Hadis 5:

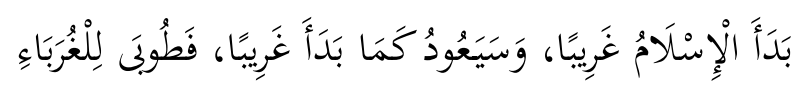

Hadis ini diriwayatkan oleh Imam Muslim, Imam Ibn Majah, dan Imam Ahmad dari Abu Hurairah. Karena Imam Muslim mencantumkan dalam kitab Sahih-nya (Al-Qusyairy, 2000: I, 130), maka hadis ini disimpulkan berkualitas sahih.

\section{Hadis 6:}

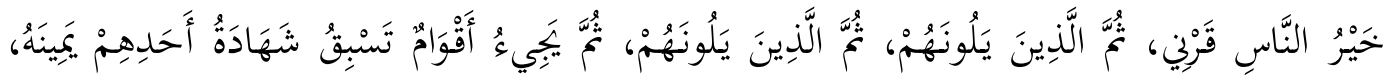

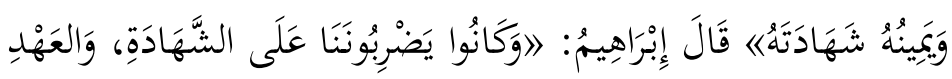

Hadis ini diriwayatkan dalam empat kitab mu'tabar, khususnya oleh Imam Bukhari (Al-Bukhari, 1422: III, 171) dan Imam Muslim (Al-Qusyairy, 2000: IV, 1963). Maka hadis ini disimpulkan berkualitas sahih.

Hadis 7:

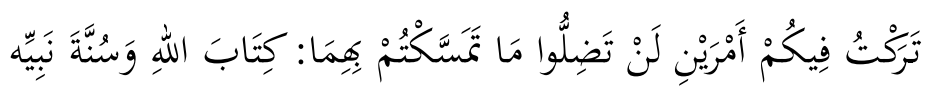


Hadis ini diriwayatkan oleh Imam Malik secara mursal, namun hadis ini dinilai hasan oleh Imam al-Tabrizi (Al-Tabrizi, 1985: I, 66). Maka disimpulkan hadis ini berkualitas hasan.

Hadis 8:

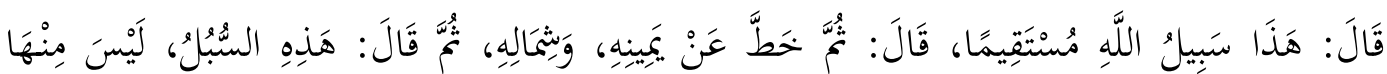

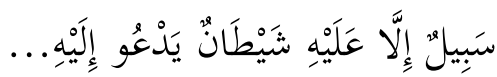

Hadis IqAAni diriwayatkan oleh Imam Ahmad dalam kitab al-Musnad dalam dua nomor berbeda (4142 dan 4437). Ahmad Muhammad Syakir menjelaskan bahwa hadis ini sahih, sebagaimana juga dikemukakan oleh al-Hakim dalam alMustadrak. Maka hadis ini disimpulkan berkualitas sahih.

Hadis 9:

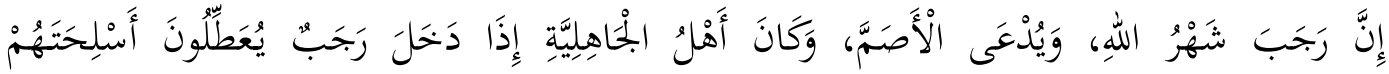

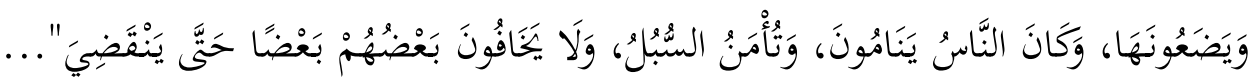

Hadis ini diriwayatkan oleh al-Baihaqi dan dalam teks di atas dijelaskan olehnya bahwa hadis ini tidak benar jika dianggap marfu sampai kepada Nabi saw.

Hadis 10:

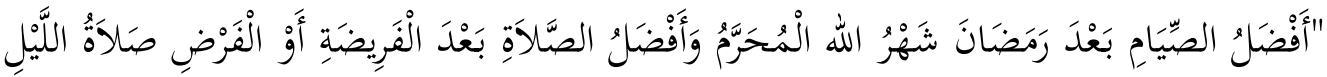

Hadis ini diriwayatkan dalam lima kitab mu'tabar, khususnya Imam Muslim dalam kitab Sahih-nya (Al-Qusyairy, 2000: II, 821) yang diperkuat oleh keterangan dari kitab Sahih Ibn Hibban (Al-Busti, 1988: VIII, 399) dan dikatakan bahwa memenuhi syarat al-Bukhari dan Muslim. Oleh karena itu, hadis ini disimpulkan berkualitas sahih.

Hadis 11:

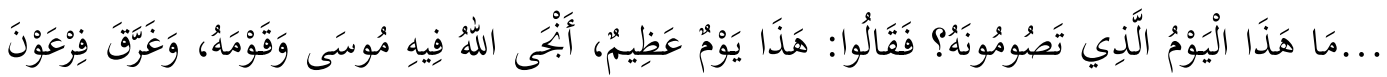

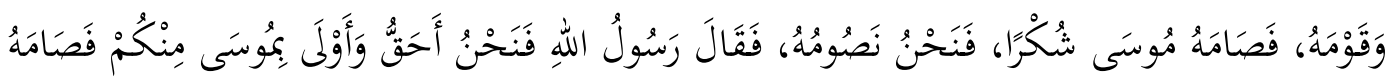

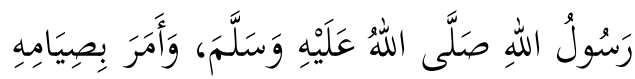

Hadis ini diriwayatkan dalam tiga kitab mu'tabar, khususnya Imam al-Bukhari dan Imam Muslim dalam kitab Sahih mereka masing-masing (Al-Bukhari, 1422: IV, 153) (Al-Qusyairy, 2000: II, 796), sehingga hadis ini dinilai berkualitas sahih.

\section{Hadis 12:}




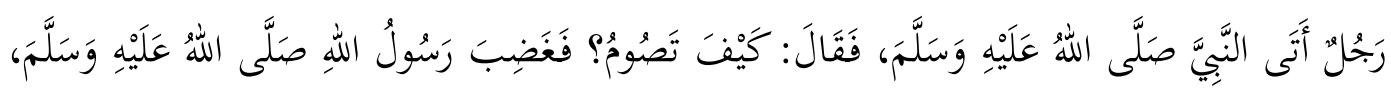

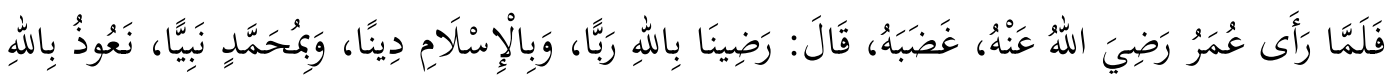

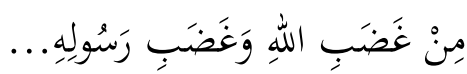

Hadis di atas diriwayatkan oleh setidaknya empat imam dalam kitab mu'tabar nya, khususnya Imam Muslim dalam kitab Sahih-nya (Al-Qusyairy, 2000: II, 818). Dengan demikian hadis ini disimpulkan berkualitas sahih.

\section{Hadis 13:}

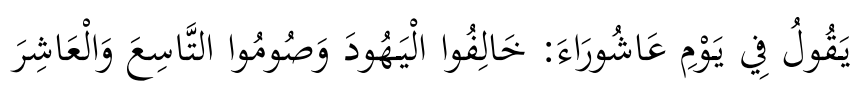

Hadis ini diriwayatkan Imam Abd al-Razzak dalam kitab al-Mushannaf dan Imam Ahmad dalam al-Musnad yang merupakan riwayat mauquf dari Ibn Abbas. Namun hadis ini memiliki jalur riwayat pendukung (berupa mutabi) yang diriwayatkan Imam Muslim yaitu:

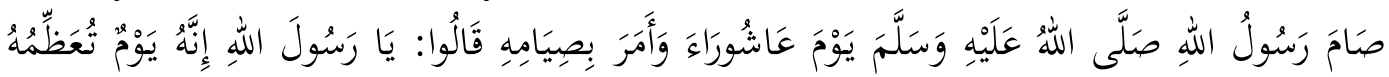

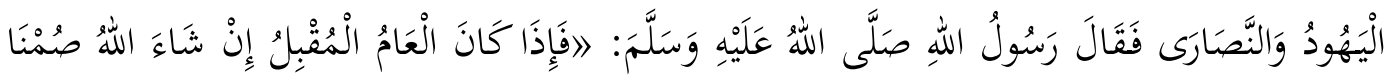

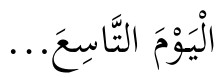

Hadis pendukung yang semakna ini berkualitas sahih, sehingga hadis yang dikaji di atas juga meningkat derajatnya, sahih ligairih.

Hadis 14:

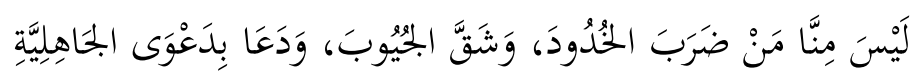

Hadis ini tercantum dalam tujuh kitab mu'tabarah/standar, khususnya Imam Bukhari dan Imam Muslim dalam sahih masing-masing (Al-Bukhari, 1422: II, 82) (Al-Qusyairy, 2000: I, 99). Oleh karena itu, hadis ini disimpulkan sahih.

Hadis 15

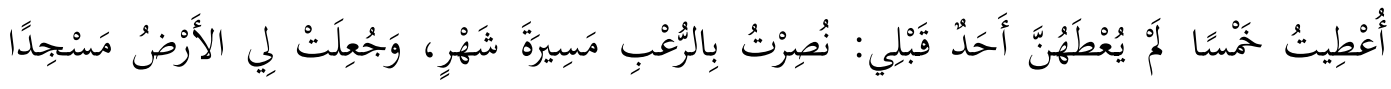

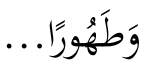

Hadis ini tercantum dalam tujuh kitab mu'tabarah/standar, khususnya Imam Bukhari dan Imam Muslim dalam sahih masing-masing (Al-Bukhari, 1422: I, 95) (Al-Qusyairy, 2000: I, 370). Oleh karena itu, hadis ini disimpulkan sahih.

Hadis 16:

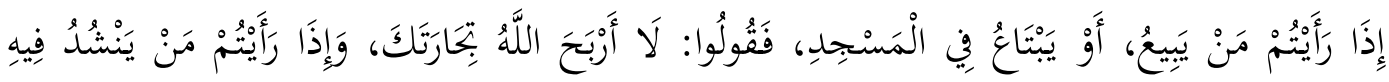

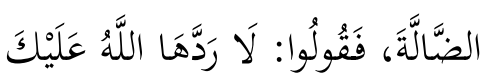


Hadis ini diriwayatkan oleh Imam al-Darimi dan Imam al-Tirmizi serta dua imam lain yang memiliki kitab sahih yaitu Imam Ibnu Khuzaimah (Khuzaimah, 2003: I, 642) dan Imam Ibn Hibban (Al-Busti, 1988: IV, 528). Dengan penilaian dari kedua imam dalam kitab sahih-nya tersebut ditambah dengan keterangan dari Syuaib al-Arnauth (Majah, 2009: II, 306) yang juga men-sahih-kannya, maka hadis ini disimpulkan berkualitas sahih.

Hadis 17:

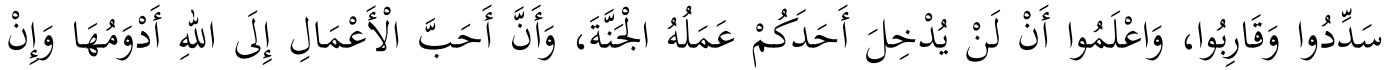

Hadis ini diriwayatkan Imam Ahmad dalam al-Musnad dari Aisyah ra. Syuaib alArnauth menjelaskan jalur bahwa hadis ini secara sendiri berkualitas hasan karena adanya seorang periwayat yang terkenal tadlis yaitu Muhammad bin Ishaq (Hanbal, 1995: XLIII, 334). Namun hadis ini memiliki jalur riwayat pendukung selevel tabi'in (mutabi) yang juga diriwayatkan Imam Ahmad (Hanbal, 1995: XLII, 268) berkualitas sahih sehingga mengangkat derajatnya menjadi sahih ligairih.

Hadis 18:

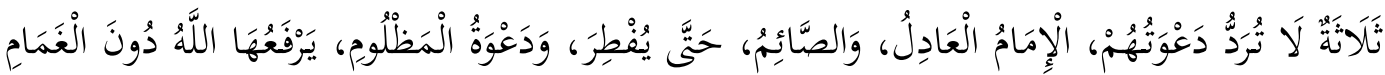

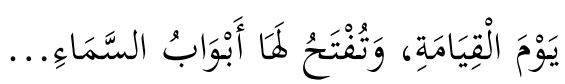

Hadis ini diriwayatkan setidaknya oleh empat imam yaitu Imam Ahmad, Imam alTirmizi, dan Imam Ibn Majah, termasuk penulis kitab sahih yaitu Ibn Hibban. Hadis ini pada dasarnya dinilai da'if oleh al-Albani namun ada bagian lafalnya yang dianggap sahih (M. N. al-D. Al-Albani, 1992: II, 534), namun ada jalur periwayatan lain yang sanadnya hasan seperti riwayat Imam al-Tirmizi sebagaimana dijelaskan juga dalam Sunan Ibn Majah (Majah, 2009: II, 636) dan Ibn Hibban (Al-Busti, 1988: VIII, 215).

Hadis 19:

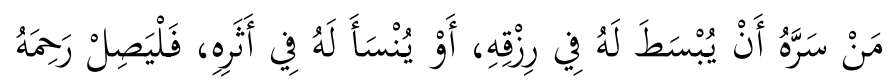

Hadis ini diriwayatkan oleh dua penulis kitab Sahih yaitu Imam Bukhari (AlBukhari, 1422: III, 56) dan Imam Muslim (Al-Qusyairy, 2000: IV, 1982), sehingga hadis ini disimpulkan sebagai hadis sahih.

Hadis 20:

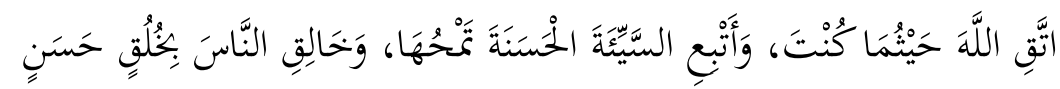

Hadis ini diriwayatkan Imam Ahmad dalam al-Musnad, Imam al-Tirmizi dan Imam al-Darimi dalam Sunan-nya masing-masing. Syuaib al-Arnauth menjelaskan bahwa hadis ini hasan ligairih (Hanbal, 1995: XXXV, 284). Dalam Al-Munzir Vol. 12. No. 1 Mei 2019 
kitab Imam Tirmizi disebutkan bahwa ada jalur periwayatan Abu Hurairah yang berkualitas hasan sahih (Al-Tirmizi, 1975: IV, 355). Oleh karena itu, hadis ini disimpulkan berkualitas hasan ligairih.

Hadis 21:

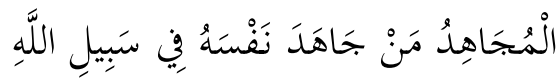

Hadis ini diriwayatkan Imam Ahmad dan Imam al-Tirmizi. Syuaib al-Arnauth dalam tahqiq Musnad Ahmad menyebutkan bahwa hadis ini sahih (Hanbal, 1995: XXXIX, 375). Sedangkan dalam kitab Sunan a-Tirmizi disebutkan bahwa hadis ini hasan sahih (Al-Tirmizi, 1975: III, 217). Ibn Hibban (Al-Busti, 1988: XI, 5) dan al-Albani menilainya hadis sahih. Oleh karena itu, hadis ini disimpulkan berkualitas sahih.

Hadis 22:

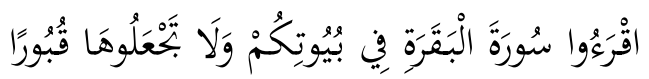

Hadis ini diriwayatkan oleh al-Baihaqi dalam Syuab al-Iman. Oleh al-Albani, hadis ini dinilai da'if (Al-Albani, n.d.: 151). Namun ada riwayat semakna yang diriwayatkan oleh al-Hakim dalam al-Mustadrak dan dihukuminya sahih menurut kriteria al-Bukhari dan Muslim (Al-Naisaburi, 1990: I, 749). Oleh karena itu, hadis ini disimpulkan hasan ligairih.

Hadis 23:

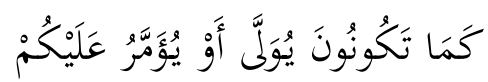

Hadis ini diriwayatkan oleh al-Baihaqi dalam Syuab al-Iman dan Muhammad bin Salamah al-Misri dalam kitabnya Musnad al-Syihab. Al-Albani menilai hadis ini sebaga hadis da'if karena mursal (Al-Albani, 1992: I, 490). Dengan demikian, hadis ini disimpulkan $d a$ 'if.

Hadis 24:

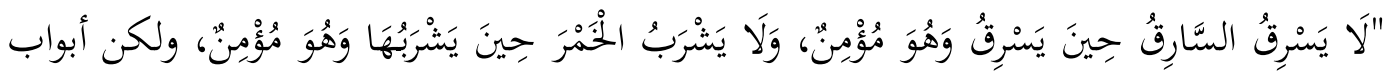

التوبة معروضة

Hadis ini diriwayatkan oleh al-Tabrani dalam al-Mu'jam al-Ausat dan oleh Ibn Hibban dalam Sahih-nya. Dalam Sahih Ibn Hibban dijelaskan bahwa hadis ini sahih berdasarkan kriteria Imam Bukhari (Al-Busti, 1988: XI, 260). Oleh karena itu, hadis ini disimpulkan berkualitas sahih.

Hadis 25:

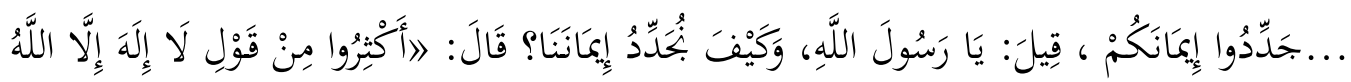

Hadis ini diriwayatkan Imam Ahmad dan di dalam Musnad-nya dijelaskan bahwa hadis ini adalah hadis hasan (Hanbal, 1995: VIII, 395). Bahkan Imam al- 
Hakim dalam al-Mustadrak menyatakannya sahih (Al-Naisaburi, 1990: IV, 285). Kedua pandangan ini tentu tidak bertentangan karena keduanya tetap bisa dijadikan hujjah.

Hadis 26:

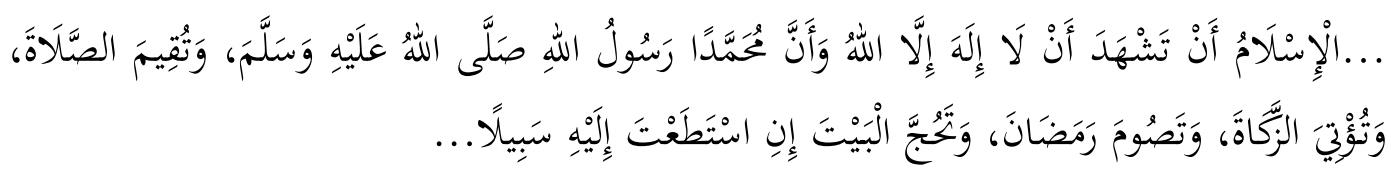

Hadis ini adalah hadis yang masyhur tentang rukun Iman dan rukun Islam yang diriwayatkan oleh Abu Dawud dalam Sunan dan oleh Imam Muslim dalam kitab Sahih-nya (Al-Qusyairy, 2000: I, 36). Oleh karena itu, hadis ini dihukumi sebagai hadis sahih.

Hadis 27:

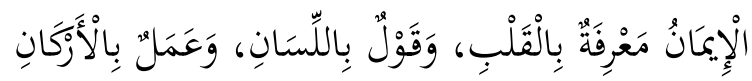

Hadis ini diriwayatkan Imam Ibn Majah dimana dijelaskan oleh al-Arnauth sebagai khabar bathil maudhu' (Majah, 2009: I, 46), riwayat keliru dan palsu. Penilaian ini diperkuat oleh keterangan al-Albani bahwa hadis ini palsu karena seorang periwayat hadis ini bernama Abd al-Salam bin Salih Abu al-Shalt alHarawi adalah seorang pemalsu hadis tertuduh berdusta oleh banyak kritikus hadis (Al-Albani, 1992: V, 295). Oleh karena itu, hadis ini disimpulkan sebagai hadis palsu.

Hadis 28:

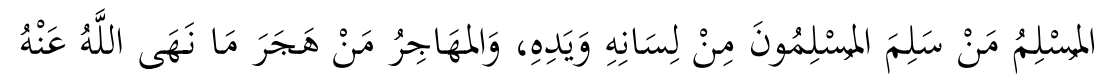

Hadis ini diriwayatkan oleh tujuh ulama hadis dalam masing-masing kitab mu'tabarnya, termasuk Imam Bukhari dan Imam Muslim. Oleh karena itu, hadis ini dinyatakan sahih.

Hadis 29:

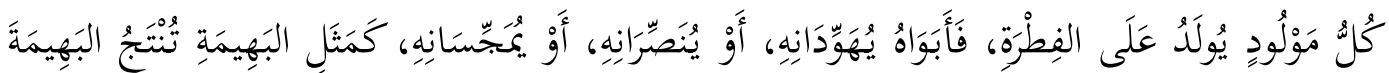
هَلْ تَرَى فِيَهَا جَذْعَاءَ

Hadis ini diriwayatkan oleh dua ulama Imam al-Bukhari dan Imam Muslim dalam kitab Sahih masing-masing, sehingga hadis ini disimpulkan sebagai hadis sahih.

Hadis 30:

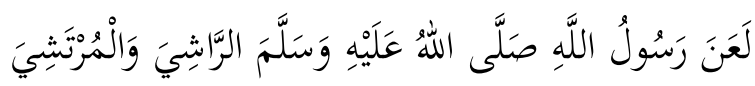

Hadis ini diriwayatkan dalam Musnad Ahmad, Sunan Abu Dawud, dan Sunan Ibn Majah. Dalam Sunan Ibn Majah dijelaskan bahwa sanad hadis ini qawi (kuat). (Majah, 2009: III, 411) Senada dengan keterangan dalam kitab Musnad Ahmad 
yang menyatakan bahwa sanad hadis ini sahih (Hanbal, 1995: VI, 100). Oleh karena itu, hadis ini disimpulkan berkualitas sahih.

Hadis 31:

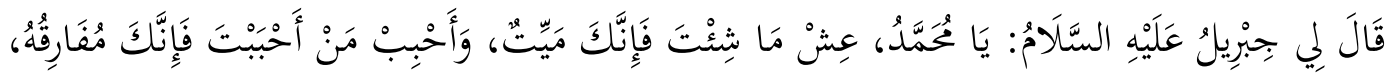

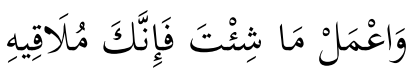

Hadis ini diriwayatkan oleh Imam al-Baihaqi dan Imam Abu Dawud al-Tayalisi. Al-Albani menilainya sebagai hadis hasan (Al-Albani, n.d.-b: 76). Sedangkan Imam al-Hakim dalam al-Mustadrak menjelaskan hadis ini sebagai hadis sahih (Al-Naisaburi, 1990: IV, 360). Dengan demikian hadis ini dinilai sebagai hadis sahih.

Hadis 32:

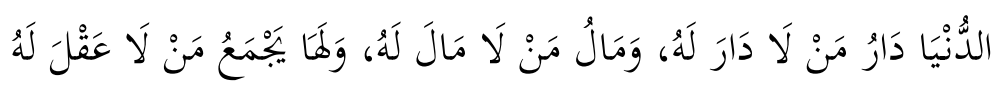

Hadis ini diriwayatkan dalam Musnad Ahmad dan dijelaskan oleh Syuaib alArnauth bahwa hadis ini da 'if (Hanbal, 199b5: LX, 460). Senada dengan penilaian yang diberikan oleh al-Albani (Al-Albani, 1992: IV, 405). Oleh karena itu, hadis ini dinilai sebagai hadis da'if.

Hadis 33:

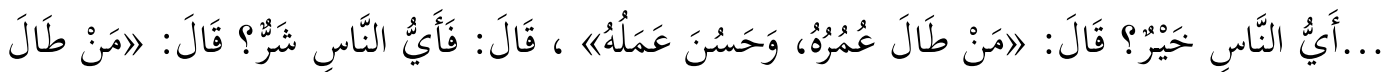

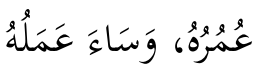

Hadis ini diriwayatkan oleh Imam Ahmad, Imam al-Darimi, Imam al-Tirmizi, dan Imam Ibn Hibban. Dalam kitab Sunan al-Tirmizi dijelaskan oleh pentahqiq nya bahwa hadis ini hasan (Al-Tirmizi, 1975: IV, 144). Al-Albani menilai hadis ini sebagai hadis sahih (Al-Albani, n.d.-b, 624). Oleh karena itu, hadis ini disimpulkan sebagai hadis sahih.

Hadis 34:

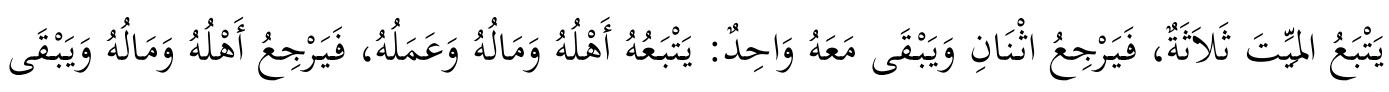
عَمَلُهُ

Hadis ini diriwayatkan oleh dua penulis kitab Sahih yaitu Imam Bukhari dan Imam Muslim di samping diriwayatkan oleh Imam al-Nasa'i. Berdasar kepada kitab Sahihain, maka hadis ini disimpulkan sebagai hadis sahih.

Hadis 35:

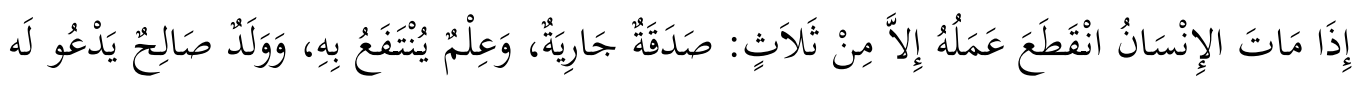

Hadis ini diriwayatkan oleh tiga ulama penulis kitab sunan, yaitu Imam alTirmizi, Imam Abu Imam Dawud, dan Imam al-Darimi, dan Imam Muslim dan Al-Munzir Vol. 12. No. 1 Mei 2019 
Imam Ibn Hibban dalam Sahih-nya masing-masing. Al-Arnauth dalam tahqiq kitab Abu Dawud menyatakan bahwa hadis ini sahih (Al-Sijistani, 2009: IV, 506). Di samping itu, hadis ini disahihkan Imam Muslim. Oleh karena itu, hadis ini disimpulkan sebagai hadis sahih.

Hadis 36:

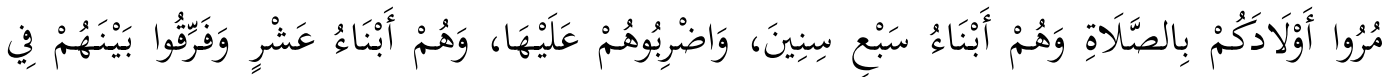<smiles>[Al]=[As]</smiles>

Hadis ini diriwayatkan oleh Imam Abu Dawud dalam Sunan-nya. Kajian alAlbani terhadap hadis-hadis Abu Dawud menjelaskan bahwa hadis ini adalah hadis hasan sahih. Beliau juga mengutip pandangan al-Nawawi yang menyatakan bahwa sanad hadis ini hasan (Al-Albani, 2002: II, 401). Oleh karena itu, hadis ini dihukumi hasan.

Hadis 37:

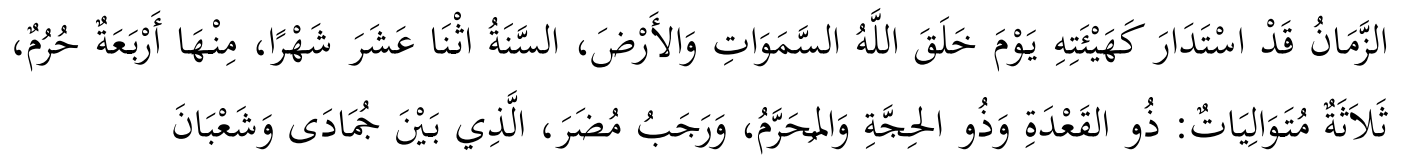

Hadis ini diriwayatkan oleh Imam al-Bukhari dan Imam Muslim dalam Sahih-nya masing-masing, sehingga hadis ini dihukumi hadis sahih.

Hadis 38:

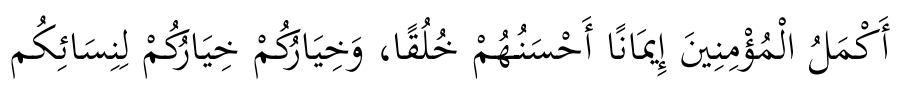

Hadis ini diriwayatkan oleh Imam Ahmad dan tiga penulis kitab sunan yaitu Imam al-Tirmizi, Imam al-Darimi, dan Imam Abu Dawud. Imam Ahmad menjelaskan bahwa sanad hadis ini sahih (Hanbal, 1995: VII, 208). Sementara Imam al-Tirmizi menyatakan hadis ini hasan sahih (Al-Tirmizi, 1975: II, 457). Al-Hakim menilai hadis ini sebagai hadis sahih (Al-Naisaburi, 1990: I, 43). Oleh karena itu, hadis ini disimpulkan sebagai hadis sahih.

Hadis 39:

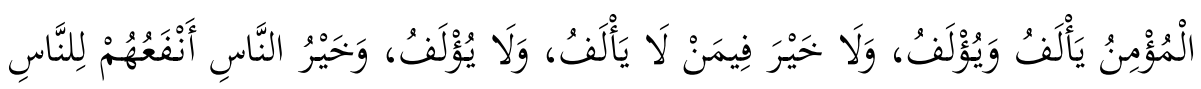

Hadis ini diriwayatkan oleh Imam al-Tabrani dalam al-Mu'jam al-Ausat. AlAlbani menjelaskan dalam kitab Sahih al-Jami al-Shagir bahwa hadis ini hasan (Al-Albani, n.d.-b: I, 623) Sementara dalam Silsilah al-Sahihah bahwa hadis ini adalah hadis dengan periwayat-periwayat tsiqah sehingga hadisnya sahih (AlAlbani, 1995: I, 787). Oleh karena itu, hadis ini disimpulkan sebagai hadis sahih.

Hadis 40:

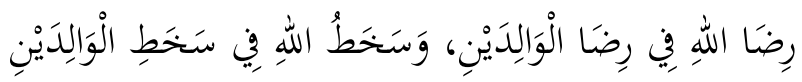


Hadis dengan redaksi di atas diriwayatkan oleh al-Baihaqi dalam Syuab al-Iman. Sementara hadis dengan makna yang sama diriwayatkan oleh Imam al-Tirmizi, Imam al-Hakim, dan Imam Ibn Hibban dengan redaksi berikut:

$$
\text { رِضَاءُ اللَّهِ فِي رِضَاء الْوَالِدِ، وَسَخَطُ اللَّهِ فِي سَخَطِط الْوَال }
$$

hadis ini adalah hadis sahih sebagaimana dijelaskan oleh Imam al-Hakim (AlNaisaburi, 1990: IV, 168), dan Imam Ibn Hibban (Al-Busti, 1988: II, 172). Oleh karena itu, hadis ini disimpulkan berkualitas sahih.

Hadis 41:

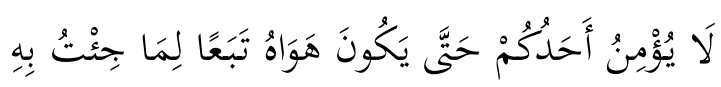

Hadis ini diriwayatkan oleh Ibn Abi Ashim dalam kitabnya al-Sunnah. Dalam komentar al-Albani terhadap hadis-hadis dalam kitab tersebut dijelaskan bahwa hadis ini memiliki sanad yang da'if karena ada seorang periwayat bernama Naim bin Hammad yang terlalu banyak keliru (Ashim, 1980: I, 12). Hal ini senada dengan penilaian al-Tabrizi dalam kitab Misykat (Al-Tabrizi, 1985: I, 59). Oleh karena itu, hadis ini dihukumi sebagai hadis da'if.

Hadis 42:

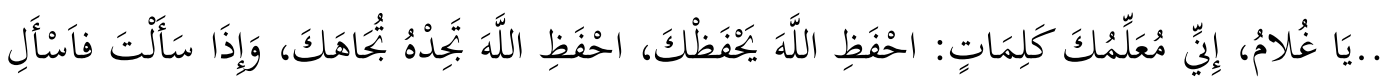

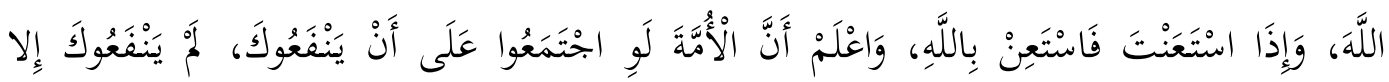

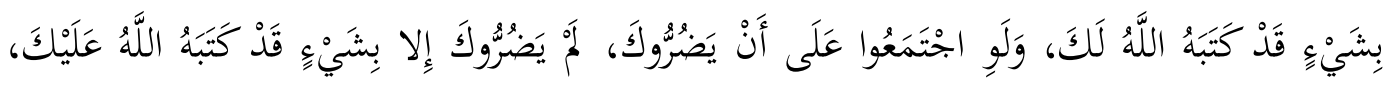

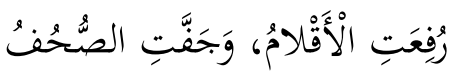

Hadis ini diriwayatkan oleh Imam Ahmad, hadis ini dinilai sahih.

Hadis 43:

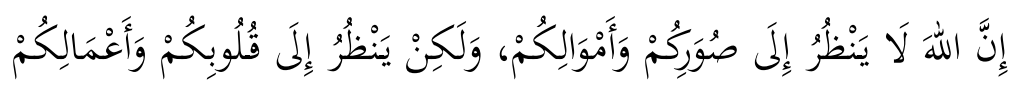

Hadis ini diriwayatkan oleh Imam Ahmad dan Imam Ibn Majah, selain itu juga diriwayatkan oleh Imam Muslim dan Imam Ibn Hibban. Oleh karena itu, hadis ini disimpulkan berkualitas sahih.

Hadis 44:

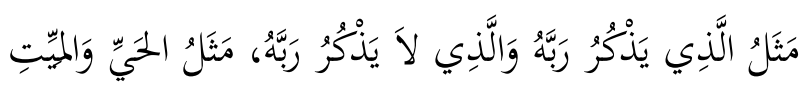

Hadis ini diriwayatkan oleh dua ulama penulis kitab sahih yaitu Imam al-Bukhari dan Imam Ibn Hibban, sehingga hadis ini disimpulkan berkualitas sahih. 
Hadis 45:

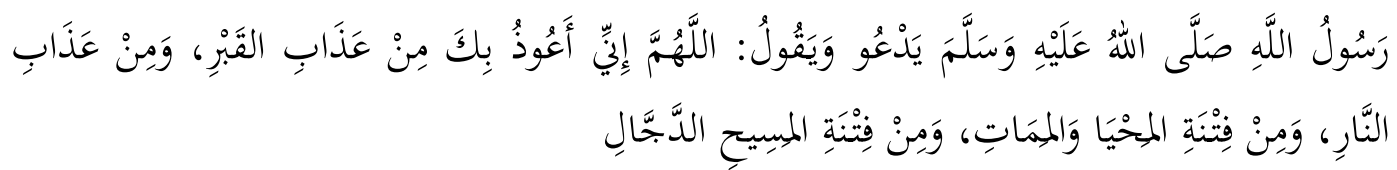

Hadis ini diriwayatkan oleh Imam Abu Dawud, Imam al-Tirmizi, Imam alDarimi, Imam Ahmad, dan dua penulis kitab sahih yaitu Imam al-Bukhari dan Imam Muslim. Oleh karena itu, hadis ini dihukumi sahih.

Hadis 46:

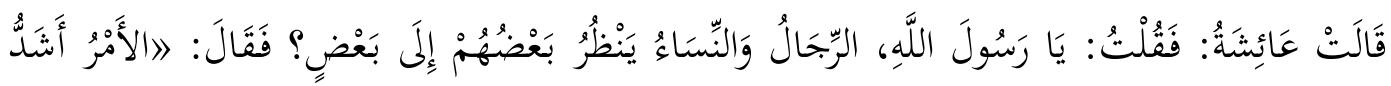

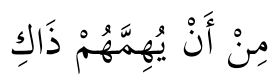

Hadis ini diriwayatkan oleh Imam Abu Dawud, Imam al-Tirmizi, Imam alDarimi, Imam al-Nasa'i, dan dua penulis kitab sahih yaitu Imam al-Bukhari dan Imam Muslim. Oleh karena itu, hadis ini dihukumi sahih.

Hadis 47:

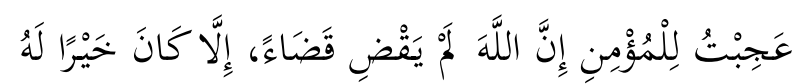

Hadis ini diriwayatkan oleh Imam Ahmad dan Imam Ibn Hibban. Dalam kedua kitab tersebut dikemukakan bahwa hadis ini adalah hadis sahih (Hanbal, 1995: XIX, 203) (Al-Busti, 1988: II, 507). Oleh karena itu, hadis ini disimpulkan sebagai hadis sahih.

Hadis 48:

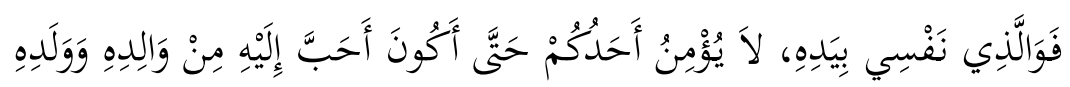

Hadis ini diriwayatkan oleh Imam Ahmad, Imam al-Tirmizi, Imam Ibn Majah, Imam al-Nasa'i, dan dua penulis kitab sahih yaitu Imam al-Bukhari dan Imam Muslim. Oleh karena itu, hadis ini dihukumi sahih.

Hadis 49:

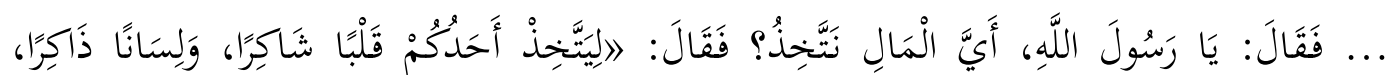

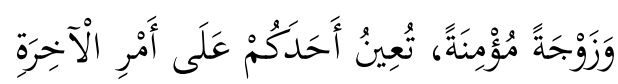

Hadis ini diriwayatkan oleh Imam Ibn Majah, Imam Abu Dawud, dan Imam Ahmad. Sanad hadis ini da'if karena terputusnya periwayatan antara Salim dan Tsauban, namun ada jalur periwayatan lain yang berkualitas hasan yang mengangkat derajatnya menjadi hasan ligairih (Majah, 2009: III, 61).

Hadis 50: 


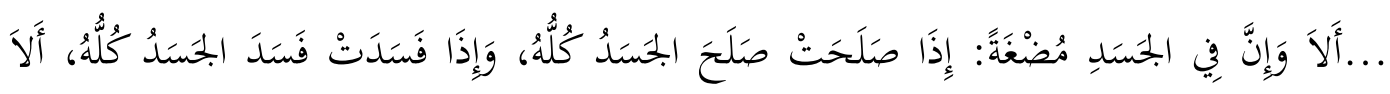
وَهِيَ العَلْبُ

Hadis ini diriwayatkan oleh Imam Ahmad, Imam Ibn Majah, Imam al-Darimi, dan dua penulis kitab sahih yaitu Imam al-Bukhari dan Imam Muslim. Oleh karena itu, hadis ini dihukumi sahih.

\section{Hadis 51:}

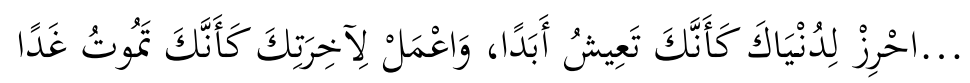

Hadis ini diriwayatkan adalah hadis mauquf dari salah satu sahabat Nabi saw. dan tidak sampai marfu kepada Nabi saw.

Hadis 52:

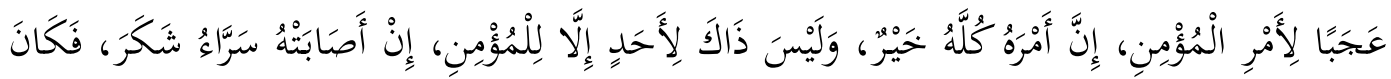

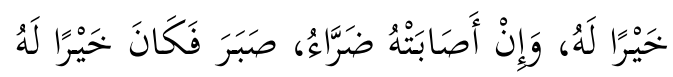

Hadis ini diriwayatkan oleh Imam Ahmad dalam al-Musnad dan Imam Muslim dalam Sahih-nya. Oleh karena itu, hadis ini disimpulkan berkualitas sahih.

Hadis 53:

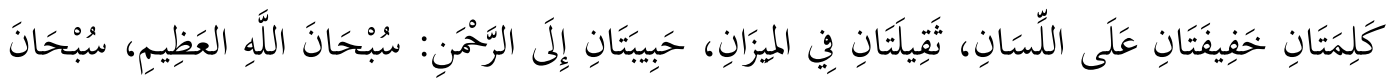
اللَّهِ وَبَحَمْدِدِهِ

Hadis ini diriwayatkan oleh Imam Ahmad, Imam al-Tirmizi, Imam Ibn Majah, dan dua penulis kitab sahih yaitu Imam al-Bukhari dan Imam Muslim. Oleh karena itu, hadis ini dihukumi sahih.

\section{Hadis 54:}

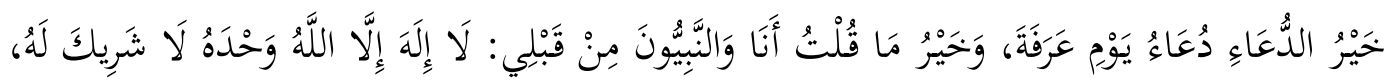

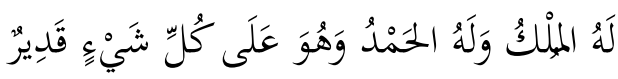

Hadis ini diriwayatkan oleh Imam Malik, Imam al-Tirmizi, Imam Ahmad dan Imam Ibnu Hibban. Al-Albani menilai hadis ini sebagai hadis hasan (Al-Albani, n.d.-b: I, 248), sementara al-Tabrizi menilainya hadis sahih (Al-Tabrizi, 1985: II, 797). Oleh karena itu, hadis ini disimpulkan sebagai hadis sahih.

Hadis 55:

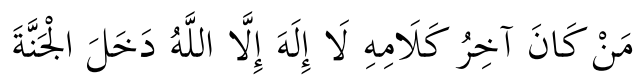


Hadis ini diriwayatkan oleh Imam Ahmad, Imam Abu Dawud, dan salah satu penulis kitab sahih yaitu Imam Muslim. Oleh karena itu, hadis ini dihukumi sahih.

\section{Hadis 56:}

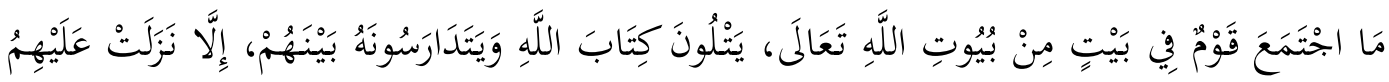

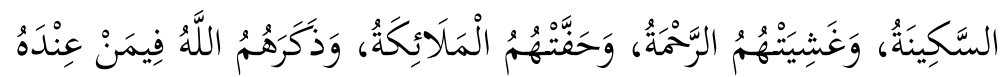

Hadis ini diriwayatkan oleh Imam Abu Dawud dan salah satu penulis kitab sahih yaitu Imam Muslim. Oleh karena itu, hadis ini dihukumi sahih.

Hadis 57:

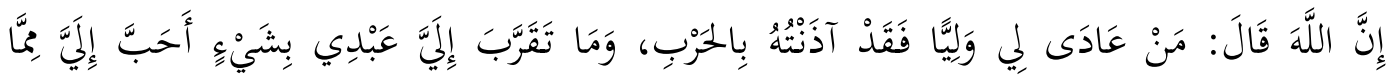

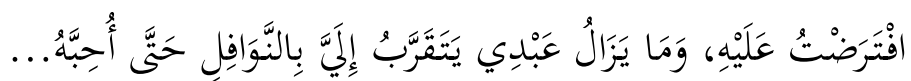

Hadis ini diriwayatkan oleh Imam Ahmad dan salah satu penulis kitab sahih yaitu Imam al-Bukhari. Oleh karena itu, hadis ini dihukumi sahih.

Hadis 58:

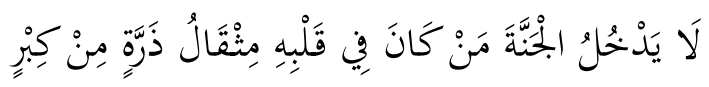

Hadis ini diriwayatkan oleh Imam Ahmad, Imam al-Tirmizi, dan salah satu penulis kitab sahih yaitu Imam Muslim. Oleh karena itu, hadis ini dihukumi sahih.

Hadis 59:

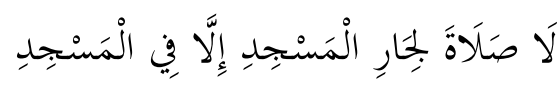

Hadis ini diriwayatkan oleh Imam al-Daruquthni dan Imam Abd al-Razzaq. AlBaihaqi menilainya hadis da'if yang senadan dengan al-Albani yang melihat adanya seorang periwayat bernama Sulaiman bin Dawud al-Yamami yang sangat lemah (da'if jiddan) (Al-Albani, 1992: I, 332) Oleh karena itu, hadis ini disimpulkan berkualitas $d a$ 'if.

Hadis 60:

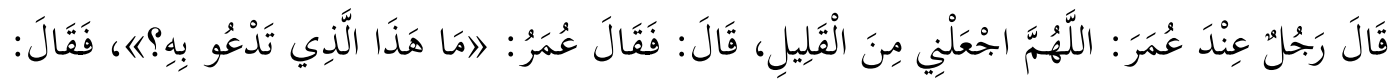

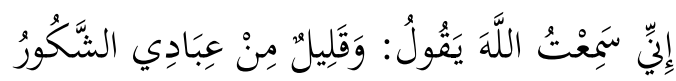

Hadis ini diriwayatkan oleh Ibn Abi Syaibah dengan status mauquf kepada sahabat dan tidak marfu sampai kepada Nabi saw.

Hadis 61:

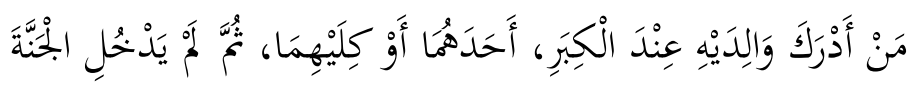


Hadis ini diriwayatkan oleh Imam Ahmad dan salah satu penulis kitab sahih yaitu Imam Muslim. Oleh karena itu, hadis ini dihukumi sahih.

Hadis 62:

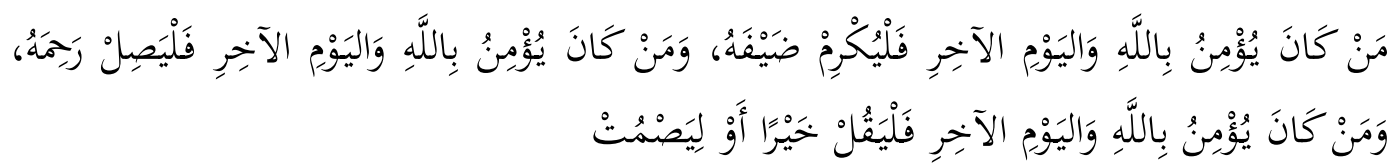

Hadis ini diriwayatkan oleh Imam Ahmad, Imam Abu Dawud, Imam al-Tirmizi, Imam al-Darimi, Imam al-Nasa'i, dan dua penulis kitab sahih yaitu Imam alBukhari dan Imam Muslim. Oleh karena itu, hadis ini dihukumi sahih.

Hadis 63:

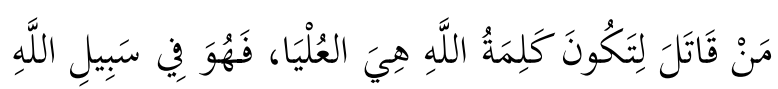

Hadis ini diriwayatkan oleh Imam Ahmad, Imam al-Tirmizi, Imam Ibn Majah, Imam al-Nasa'i, dan dua penulis kitab sahih yaitu Imam al-Bukhari dan Imam Muslim. Oleh karena itu, hadis ini dihukumi sahih.

Demikianlah hasil dari penelitian terhadap kualitas hadis yang disampaikan oleh khatib-khatib selama penelitian ini di Kota Kendari. Dari pembahasan di atas, dapat disimpulkan bahwa hadis-hadis dengan kualitas sahih dan hasan (dijadikan hujjah) yang disampaikan oleh khatib di Kota Kendari sangat tinggi, dimana dari 66 hadis yang ditemukan, 54 diantaranya adalah hadis sahih dan hasan, hanya 5 yang berkualitas da'if, 1 yang maudhu (palsu), dan selebihnya 3 hadis mauquf dan 3 lainnya tidak ditemukan teks hadisnya dalam kitab-kitab hadis.

Dibandingkan dengan hasil penelitian hadis khutbah yang pernah dilakukan sebelumnya seperti di Bengkulu (Supian, Fairuzzabadi, \& Emzinetri, 2016), Aceh (Hakim, 2015), Berau Kalimantan Timur (Fatkhi, 2017), dan Kabupaten Bogor (Cahyani, 2018), hasil penelitian hadis khutbah di Kota Kendari menunjukkan tren yang sangat positif, karena tingkat penggunaan hadis-hadis yang berkualitas sahih dan hasan yang sangat tinggi. Hal ini sekaligus menunjukkan bahwa secara umum dai Kota Kendari lebih memiliki perhatian dan penguasaan hadis yang lebih baik, meskipun masih ditemukan individu tertentu yang kurang memperhatikan hadis dalam penyampaian khutbahnya, termasuk adanya beberapa kekeliruan dalam membaca dan menyampaikan hadis. 


\section{Kesimpulan}

Tingkat penggunaan hadis dalam khutbah jika diratakan memang terkesan cukup tinggi, karena dari 47 data khutbah yang diperoleh ditemukan 76 kali hadis disebutkan dengan 33 dari 47 khatib menyampaikan hadis. Namun jika dilihat dari sisi lain adanya 14 khatib lainnya tidak menyampaikan hadis sama sekali, justru menghadirkan kesan lain akan adanya khatib-khatib tertentu yang kurang memperhatikan hadis dalam khutbah mereka. Dalam konteks metode penyampaian hadis, peneliti tidak menemukan bentuk ideal dalam hal memberi edukasi hadis kepada jamaah. Dalam hal ini peneliti menemukan 6 ragam penyampaian hadis, meski tidak mempengaruhi keabsahan khutbah, peneliti memandang bahwa akan sangat afdhal jika sebuah hadis disampaikan tidak sekadar menyampaikan maksudnya, akan tetapi mengedukasi jamaah untuk melihat sisi lain dari hadis yang berbeda dengan al-Qur'an agar masyarakat terbiasa untuk akrab dan mengkaji hadis lebih lanjut. Dalam penelitian juga ditemukan sejumlah kesalahan dalam penyampaian hadis, mulai dari kekeliruan membaca, salah menyebutkan hadis yang dianggap ayat, sampai kepada kesalahan menisbahkan hadis palsu kepada ulama seperti al-Bukhari.

Kualitas hadis-hadis yang disampaikan khatib dalam khutbah Jumat di Kota Kendari sangat baik. Total 76 kali hadis disebutkan, 10 hadis diantaranya sama, sehingga total akhir adalah 66 hadis. 63 hadis dapat ditemukan dalam kitab-kitab hadis, 3 di antaranya tidak dapat ditemukan. Rujukannya pun menunjukkan tren positif, karena 52 hadis diantaranya terdapat dalam kitab-kitab standar (al-kutub al-tis'ah) dan hanya 11 yang terdapat di kitab-kitab non-standar. Setelah diteliti kualitas hadis-hadis tersebut, 55 diantaranya adalah hadis sahih dan hasan, hanya 4 yang berkualitas da' if, 1 yang maudhu (palsu), dan selebihnya 3 hadis mauquf dan 3 lainnya tidak ditemukan teks hadisnya dalam kitab-kitab hadis. Hasil tersebut menunjukkan tren yang positif, karena tingkat penggunaan hadis-hadis yang berkualitas sahih dan hasan yang tinggi. Hal ini sekaligus menunjukkan bahwa secara umum dai Kota Kendari lebih memiliki perhatian dan penguasaan hadis yang lebih baik, meskipun masih ditemukan individu tertentu yang kurang memperhatikan hadis dalam penyampaian khutbahnya, termasuk adanya beberapa kekeliruan dalam membaca dan menyampaikan hadis. 


\section{Daftar Pustaka}

Al-Albani, N. al-D. (n.d.-a). Da'if al-Jami al-Shagir wa Ziyadatuh. al-Maktab alIslami.

Al-Albani, N. al-D. (n.d.-b). Sahih al-Jami al-Shagir wa Ziyadatuh. al-Maktab alIslami.

Al-Albani, N. al-D. (1420). Da 'if Abi Dawud. Kuwait: Muassasah Garras.

Al-Albani, N. al-D. (1992). Silsilah Ahadits al-Dhaifah wa al-Maudhu'ah. Riyadh: Dar al-Ma'arif.

Al-Albani, N. al-D. (1995). Silsilah Ahadis al-Sahihah. Riyadh: Maktabah alMa'arif.

Al-Albani, N. al-D. (2002). Sahih Abi Dawud. Kuwait: Muassasah Garras.

Al-Bukhari, M. bin I. (1422). Sahih al-Bukhari. Makkah: Dar Thuq al-Najah.

Al-Busti, M. bin H. (1988). Al-Ihsan fi Taqrib Sahih Ibn Hibban. Bairut: Muassasah al-Risalah.

Al-Naisaburi, A. A. al-H. (1990). al-Mustadrak ala al-Sahihain. Bairut: Dar alKutub al-Ilmiyah.

Al-Qusyairy, M. ibn A.-H. (2000). Sahih Muslim. New Delhi: Kitab Bhavan.

Al-Sijistani, A. D. S. (2009). Sunan Abi Dawud. (S. Al-Arnauth, Ed.). Dar alRisalah al-Alamiyah.

Al-Tabrizi, M. bin A. A.-K. al-U. (1985). Misykat al-Mashabih. (N. al-D. AlAlbani, Ed.). Bairut: Maktabah al-Islami.

Al-Tirmizi, M. bin I. (1975). Sunan al-Tirmizi. (I. Athwah, Ed.). Mesir: Maktabah al-Babiy al-Halabi.

Ashim, A. B. bin A. (1980). Kitab al-Sunnah. al-Maktab al-Islami.

Cahyani, A. I. D. (2018). Kualitas Dan Akurasi Hadis-Hadis Yang Disampaikan

Khatib Jum'at Dan Penceramah Di Kabupaten Bogor. Jakarta: Fakultas Ushuluddin Dan Filsafat UIN Syarif Hidayatullah.

Fatkhi, R. M. (2017). Kritik hadis-hadis yang disampaikan para khatib di khutbah jum'at. UIN Syarif Hidayatullah Jakarta: Fakultas Ushuluddin, 2017.

Hakim, M. (2015). Kualitas Hadis-Hadis dalam Khutbah Jumat (Studi Kasus di Mesjid Baitusshadiqin Baet-Cadek Aceh Besar). UIN Ar-Raniry Banda Aceh.

Al-Munzir Vol. 12. No. 1 Mei 2019 
Hanbal, A. A. A. bin M. bin. (1995). Musnad Ahmad. Kairo: Dar al-Hadis.

Khuzaimah, M. bin I. I. (2003). Sahih Ibn Khuzaimah. (M. M. A'zami, Ed.). alMaktab al-Islamiy.

Majah, M. bin Y. al-Q. I. (2009). Sunan Ibn Majah. (S. Al-Arnauth, Ed.). Dar alRisalah al-Alamiyah.

Rusli, M., \& HPW, N. H. (2017). Problematika dan Solusi Masa Depan Hadis dan Ulumul Hadis.

Supian, A., Fairuzzabadi, M., \& Emzinetri, E. (2016). KUALITAS HADISHADIS DALAM KHUTBAH JUMAT DI KOTA BENGKULU (Studi Kritik Sanad dan Matan). MANHAJ: Jurnal Penelitian Dan Pengabdian Masyarakat, 4(1).

Thaib, E. J. (4AD). Analisis Minat Jamaah Masjid terhadap Penyampaian Khutbah Jumat di Kecamatan Talaga Jaya Kabupaten Gorontalo. Madani. 